\title{
IMOBILISASI PROPANOLOL HCL PADA HIDROGEL POLI(VINIL ALKOHOL) - NATRIUM ALGINAT DENGAN TEKNIK RADIASI
}

\author{
Erizal $^{1}$, Erlina Widianti Pratiwi ${ }^{2}$, Dian Pribadi Perkasa ${ }^{1}$, Noviyantih $^{2}$, Basril Abbas $^{1}$, \\ dan Sudirman ${ }^{3}$ \\ ${ }^{1}$ Pusat Aplikasi Isotop dan Radiasi, BATAN, Jl. Lebak Bulus raya No.49, Jakarta Selatan 12440. \\ ${ }^{2}$ Fakultas Farmasi Universitas Pancasila, Jl. Serengseng Sawah, Depok, \\ ${ }^{3}$ Pusat Sains dan Teknologi Bahan Maju, Serpong \\ E-mail : erizal @batan.go.id
}

Received : 29 Maret 2017; revised : 10 April 2017; accepted : 23 Februari 2018

\begin{abstract}
ABSTRAK
IMOBILISASI PROPANOLOL HCL PADA HIDROGEL POLI(VINIL ALKOHOL) - NATRIUM ALGINAT DENGAN TEKNIK RADIASI. Penelitian ini bertujuan memanfaatkan hidrogel sebagai matriks imobilisasi obat dengan teknik iradiasi gamma untuk mengontrol laju pelepasan obat terkendali. Imobilisasi propanolol $\mathrm{HCl}$ dalam hidrogel poli(vinil alkohol) (PVA)-g-natrium alginat (NaAlg) telah dilakukan. Larutan PVA/NaAlg (5/0,5, \%berat) yang mengandung propanolol $\mathrm{HCl}(8 \mathrm{mg}$ sampai dengan $16 \mathrm{mg}$ ), dibeku-lelehkan (3 siklus) dan diradiasi dengan variasi dosis (10 kGy sampai dengan $30 \mathrm{kGy}$ ). Hidrogel dikarakterisasi dengan spectrophotometer Fourier Transform-Infra Red (FT-IR) dan Scanning Electron Microscope (SEM). Fraksi gel dan daya serap air ditentukan secara gravimetri. Uji pelepasan propanolol $\mathrm{HCl}$ dari hidrogel dilakukan dalam larutan encer fosfat ( $\mathrm{pH} 6,8$ ) pada suhu $37^{\circ} \mathrm{C}$ diukur dengan spectrofotomer Ultraviolet Visible (UV-Vis). Hasil evaluasi menunjukkan peningkatan dosis iradiasi dari $10 \mathrm{kGy}$ hingga $30 \mathrm{kGy}$, peningkatan fraksi gel hidrogel, dan kemampuan menyerap air hidrogel relatif turun. Pelepasan kumulatif obat dari matriks hidrogel dengan meningkatnya dosis iradiasi hingga 30 kGy relatif turun. Pengamatan menggunakan SEM, menunjukkan hidrogel PVA-NaAlg mempunyai struktur pori yang tidak teratur. Hidrogel PVA-g-NaAlg selayaknya dapat digunakan sebagai matriks pelepasan obat.
\end{abstract}

Kata kunci : Imobilisasi, Hidrogel, Poli(vinil alkohol), Propanolol HCL, Natrium alginat

\begin{abstract}
IMMOBILIZATION OF PROPANOLOL HCL IN POLY(VINYL ALCOHOL) - SODIUM ALGINATE HYDROGEL USING IRRADIATION TECHNIQUE. The aim of this work is to use hydrogels for drug immobilization matrix prepared by gamma irradiation technique for controlled release of the drug. Immobilization of propanolol $\mathrm{HCl}$ in poly(vinyl alcohol) (PVA)-sodium alginate ( $\mathrm{NaAlg}$ ) hydrogels have been carried out. The solution mixtures of PVA-NaAlg (5/0.5, wt \%) containing different content of propanolol $\mathrm{HCl}(8 \mathrm{mg}$ to $16 \mathrm{mg}$ ) were freeze-thawing for three cycles and then irradiated at various doses (10 kGy to $30 \mathrm{kGy}$ ) by gamma radiation. The chemical changes of hydrogels were characterized using Fourier Transform-Infra Red (FT-IR) and morphologies of hydrogels were investigated using Scanning Electron Microscope (SEM). The released of propanolol $\mathrm{HCl}$ were tested in aqueous solutions using UV-Vis spectrophotometer at $37{ }^{\circ} \mathrm{C}$ in buffer phosphate (pH 6.8). After evaluated it was found that with increasing irradiation doses up to $30 \mathrm{kGy}$ and the gel fraction increased. In contrast, water absorption decreased as well as the cumulative amount of drug decrease. SEM observation of hydrogel PVA-g-NaAlg surfaces showed a large heterogeneous porous and can be a candidate as a matrix for drug release controlled..
\end{abstract}

Key words : Immobilization, Hydrogel, Poly(vinyl alcohol), Propanolol HCL, Sodium alginate

\section{PENDAHULUAN}

Pada saat ini, industri farmasi dalam pembuatan produk obat sistem pelepasan obat terkendali (controlled release of drug) berkembang relatif pesat. Produk obat pelepasan terkendali tersebut didesain dengan tujuan untuk terapi tertentu yang berdasarkan atas sifat fisiko-kimia, farmakologi, dan farmakokinetik obat (Defail et al. 2006; Chowdhury 2014; Catelas, Dwyer, dan Helgerson 2008).

Propanolol $\mathrm{HCl}$ merupakan senyawa pemblok reseptor $\beta$ nonselektif yang digunakan 
sebagai obat antihipertensi. Propanolol $\mathrm{HCl}$ diabsorbsi dengan baik dalam saluran cerna dengan waktu paruh eliminasi yang pendek yaitu 3 jam. Penderita hipertensi kronik biasanya diharuskan mengkonsumsi obat antihipertensi sepanjang hidupnya untuk menjaga tekanan darah agar tetap normal. Untuk itu, obat hipertensi harus mempunyai bioavailability yang baik di dalam plasma agar berada dalam dosis terapeutik. Dengan waktu paruh eliminasi yang pendek, maka propanolol $\mathrm{HCl}$ harus sering diberikan untuk mempertahankan kadar terapi dalam plasma. Untuk efisiensi dan efektivitas dari obat, perlu dibuat sediaan obat dengan sistem pelepasan terkendali.

Produk sediaan lepas obat terkendali menjadi popular di bidang kesehatan karena beberapa faktor, antara lain dapat menghasilkan efek terapeutik dalam jangka panjang, penggunaan obat lebih efisien, memperkecil efek samping dan efek toksik akibat fluktuasi kadar obat dalam plasma, serta mengurangi frekuensi pemberian obat. Teknik imobilisasi obat ke dalam matriks hidrogel merupakan salah satu metode penghantaran obat yang diteliti dan dikembangkan pada saat ini (C. Lin dan Metters 2006; Sylman dan Neeves 2013; Elliott dan Shoichet 2015).

Hidrogel merupakan struktur jaringan tiga dimensi yang berasal dari bahan sintetis atau bahan alam yang dapat menyerap dan mempertahankan sejumlah besar air. Struktur hidrogel terdiri dari gugus hidrofilik dalam suatu jaringan polimer pada lingkungan berair. Hidrogel berkarakter fisiko-kimia yang khas, antara lain air dapat berdifusi dalam poriporinya, biocompatible, dan tidak menyebabkan iritasi pada jaringan lunak tubuh ketika kontak, oleh karena itu hidrogel banyak diaplikasikan di bidang biomedis ((Hudson et al. 2010). Sifat fisik dari hidrogel menarik perhatian khusus mengenai aplikasinya untuk pelepasan obat terkendali (drug delivery). Struktur pori dapat dikontrol melalui kerapatan ikatan silang dan afinitas yang tinggi terhadap lingkungan menyebabkannya swelling (Hoare dan Kohane 2008). Porositas memungkinkan obat masuk ke dalam matriks hidrogel dan selanjutnya dapat melepaskan obat pada suatu laju yang tergantung pada koefisien difusi dari molekul kecil dan makromolekul melalui jaringannya.

Imobilisasi obat merupakan salah satu teknik mengekang atau menjerat obat dalam suatu matriks yang pelepasannya dalam suatu media dapat dikontrol. Imobilisasi obat pada hidrogel umumnya dapat dilakukan dengan dua cara yaitu post loading dan in situ loading. Pada metode post loading, obat diabsorbsi pada matriks hasil sintesis, sedangkan pada in situ loading, formulasi obat dan jaringan hidrogel disintesis secara simultan. Pada umumnya, sintesis matriks hidrogel diperlukan crosslinker supaya matriks hidrogel menjadi tidak mudah larut bersama obat yang ditambahkan sebelum penjebakan obat. Sisa crosslinker ini dapat bersifat racun. Pada dasarnya, teknik imobilisasi obat adalah mengekang obat dalam matriks secara fisik, obat tidak mengalami reaksi kimia dengan matriks, dan obat dapat lepas dari matriks secara terkontrol dalam selang waktu tertentu.

Salah satu polimer sintetis yang potensial untuk digunakan sebagai bahan dasar untuk pengekang obat adalah poli(vinil alkohol) (PVA). PVA merupakan salah satu polimer yang larut dalam air (hydrophilic) yang paling populer penggunaannya sebagai bahan biomaterial dengan keunggulan antara lain biocompatible, tahan terhadap bahan kimia, biodegradable, dan dapat dibuat gel dengan proses beku-leleh (Guo et al. 2015; Kamoun et al. 2015; El-mohdy 2013; Dutta 2012; Erizal dan Abidin 2011). Namun demikian, PVA hidrogel hasil beku-leleh pada selang waktu tertentu mudah larut air karena PVA bersifat polimer berantai linier yang tidak efektif untuk pelepasan obat terkendali. Untuk mengatasi hal ini, dapat dilakukan kopolimerisasi dengan polimer atau monomer lainnya menggunakan crosslinker, foto inisiator, sinar ultraviolet, dan iradiasi gamma.

Selain polimer sintetis, matriks hidrogel juga dapat dibuat dari polimer alam seperti natrium alginat (NaAlg). NaAlg merupakan suatu polisakarida yang terdiri dari poli-1,4-D asam manuronat (satuan unit $M$ ) dan $\alpha-1,4,-L$-asam glukoronat (satuan unit $\mathrm{G}$ ) yang bervariasi dalam rantai ikatan kimianya. NaAlg dapat diekstraksi dari ganggang coklat jenis Sargassum dan Turbinaria, jumlahnya berlimpah, dapat diperbarui, tidak toksik, larut air, biodegradable, dan biocompatible (Masuelli dan Illanes 2014). Namun demikian, NaAlg mudah terdegradasi dan rapuh, untuk memperbaiki sifat tersebut alginat dapat dicampurkan dengan polimer vinil yang compatible dan fleksibel. Sebagian besar polimer alam meskipun telah memiliki biocompatibility dan biodegradasi, tetapi memiliki sifat mekanik yang lemah dan sulit diproses bila dibandingkan dengan polimer sintetis. Oleh karena natrium alginat dan PVA bersifat hydrophilic, maka dapat diambil hipotesis bahwa kedua polimer tersebut dapat dipadukan dengan mudah melalui ikatan hidrogen dan untuk memperkuat struktur fisiknya dilakukan proses ikatan silang dengan teknik iradiasi.

Metode imobilisasi obat dalam matriks hidrogel dengan teknik iradiasi mempunyai keunggulan antara lain polimer atau monomer sebagai matriks hidrogel dapat mengalami reaksi ikatan silang, obat dapat terjebak dalam matriks hidrogel secara simultan pada suhu rendah, tidak diperlukan crosslinker, dan produk yang dihasilkan sekaligus steril. Selain itu, untuk menjaga agar obat tidak mengalami degradasi, 
khususnya pada pemakaian PVA sebagai matriks dapat dibantu dengan proses beku-leleh sebelum proses iradiasi pada campuran larutan obat-polimer (Lee et al. 2011).

Berdasarkan deskripsi di atas, maka pada penelitian ini digunakan hidrogel paduan PVA-NaAlg yang disintesis dengan metode iradiasi gamma sebagai matriks pelepasan terkendali propanolol $\mathrm{HCl}$. Penetapan fraksi gel, daya serap air, karakterisasi menggunakan spectrophotometer FT-IR, Scanning Electron Microscope (SEM), dan uji pelepasan propanolol $\mathrm{HCL}$ dari matriks hidrogel diuji pada medium dengan $\mathrm{pH} \quad 6,8$ suhu $37^{\circ} \mathrm{C}$ menggunakan spectrophotometer UV-Vis.

\section{BAHAN DAN METODE}

\section{Bahan}

Bahan yang digunakan antara lain poli(vinil alkohol) (PVA) merek Kuraray, natrium alginat (NaAlg) merek Kishida Chemical, propanolol $\mathrm{HCl}$ merek IndoFarma, ammonium hidroksida $\left(\mathrm{NH}_{4} \mathrm{OH}\right)$, kalium dihidrogen fosfat $\left(\mathrm{KH}_{2} \mathrm{PO} 4\right)$, natrium hidroksida $(\mathrm{NaOH})$ diperoleh dari merck, dan air suling digunakan untuk pengujian pelepasan obat.

Alat yang digunakan yaitu Fourier Transform Infra Red (FTIR) merek Shimadzu IR Prestige -21 model 8000 series, untuk mengetahui perubahan struktur kimia hidrogel hasil iradiasi. Hidrogel kering hasil iradiasi dalam bentuk serbuk dicampur dengan serbuk $\mathrm{KBr}$ pada perbadingan berat $1: 200$, dimasukkan ke dalam tempat sampel (pan) dan selanjutnya dilakukan pengukuran spektrum pada rentang bilangan gelombang $4000 \mathrm{~cm}^{-1}$ sampai dengan $400 \mathrm{~cm}^{-1}$ dengan jumlah scan 20 .

Karakteristik permukaan hidrogel diinvestigasi menggunakan Scanning Electron Microscope (SEM) merek Zeiss 234 D. Hidrogel dalam bentuk kering, direndam di dalam air hingga swelling maksimum, kemudian hidrogel dibekukan dalam freezer pada suhu $-40{ }^{\circ} \mathrm{C}$ selama 48 jam. Selanjutnya dilakukan hidrogel liofilisasi menggunakan freeze dryer pada suhu $107{ }^{\circ} \mathrm{C}$ (8 jam). Hidrogel kering kemudian diamati sifat permukaannya menggunakan SEM dan direkam.

UV-Vis Spectrophotometer, UV-mini 1240 merek Shimadzu buatan Jepang, digunakan untuk mengukur panjang gelombang maksimum obat serta pengukuran konsentrasi obat yang lepas dari hidrogel.

\section{Metode}

\section{Sintesis Hidrogel PVA-NaAlg}

PVA (5 g) dilarutkan dalam $50 \mathrm{~mL}$ air suling menggunakan autoclave pada suhu 121 ${ }^{\circ} \mathrm{C}$ selama 2 jam, setelah itu larutan PVA didinginkan pada suhu kamar. NaAlg sebanyak
0,5 g dilarutkan dalam $20 \mathrm{~mL}$ air suling, kemudian kedua larutan tersebut dicampurkan dan ditambahkan air suling hingga $100 \mathrm{~mL}$ dan diaduk hingga homogen. Selanjutnya, campuran PVA-NaAlg dikemas dalam kantong plastik polipropilena (PP) dengan ukuran $10 \mathrm{~cm} \times 10 \mathrm{~cm}$ dan ditutup menggunakan sealing machine. Campuran tersebut dibekukan dalam freezer pada suhu $-20{ }^{\circ} \mathrm{C}$ selama 18 jam, kemudian dilelehkan pada suhu kamar selama 8 jam. Proses beku-leleh dilakukan hingga 3 siklus. Pada akhirnya, larutan beku PVA-NaAlg diiradiasi menggunakan sinar gamma pada dosis 10 kGy, 20 kGy, dan 30 kGy dengan laju dosis $5 \mathrm{kGy} / \mathrm{j}$ dalam irradiator IRPASENA-PAIR, BATAN

\section{Imobilisasi Propanolol $\mathrm{HCl}$ pada Matriks Hidrogel PVA-NaAlg}

Sejumlah $2 \mathrm{~mL}$ larutan campuran PVA dan NaAlg (5/0,5, \%berat) dimasukkan ke dalam masing-masing botol vial ukuran $3 \mathrm{~mL}$ yang telah berisi $8 \mathrm{mg}, 12 \mathrm{mg}$, dan $12 \mathrm{mg}$ propanolol $\mathrm{HCl}$, diaduk hingga homogen dan ditutup, kemudian dilakukan beku-leleh sebanyak 3 siklus dengan perlakuan yang sama. Botol vial hasil beku leleh yang mengandung obat diiradiasi dengan sinar gamma pada dosis 10 kGy, 20 kGy, dan 30 kGy dengan laju dosis $5 \mathrm{kGy} / \mathrm{jam}$.

\section{Fraksi Gel}

Uji fraksi gel dilakukan untuk mengetahui jumlah gel yang terbentuk dalam hidrogel, dengan mengeringkan PVA-NaAlg blangko (tidak mengandung propanolol $\mathrm{HCL}$ ) di dalam oven pada suhu $60^{\circ} \mathrm{C}$ selama $24 \mathrm{jam}$. Hidrogel kering ditimbang $\left(\mathrm{W}_{\mathrm{a}}\right)$, lalu direndam dalam air suling selama 24 jam pada suhu kamar untuk menghilangkan PVA-NaAlg yang tidak bereaksi. Hidrogel selanjutnya dikeringkan kembali dalam oven pada suhu $60{ }^{\circ} \mathrm{C}$ hingga berat konstan $\left(\mathrm{W}_{\mathrm{b}}\right)$. Fraksi gel dihitung dengan rumus sebagai berikut:

$$
\text { Fraksi gel }=\left(\mathrm{W}_{\mathrm{a}} / \mathrm{W}_{\mathrm{b}}\right) \times 100 \%
$$

$\mathrm{W}_{\mathrm{a}}$ merupakan berat hidrogel kering sebelum perendaman (g) dan $W_{b}$ merupakan berat hidrogel kering $(\mathrm{g})$ hasil ekstraksi dalam air selama 24 jam

\section{Penentuan Daya Serap Air Hidrogel}

Uji daya serap air dilakukan untuk mempelajari kemampuan hidrogel dalam menyerap air, hal ini berkaitan erat dengan pola pelepasan obat yang terimobilisasi. Hidrogel PVA-NaAlg dalam bentuk kering dengan ukuran kurang lebih $1 \mathrm{~cm} \times 1 \mathrm{~cm}$ direndam dalam air suling pada suhu kamar. Setelah selang interval waktu tertentu (yaitu 1 jam, 2 jam, 3 jam, 4 jam, 5 jam, 6 jam, dan 24 jam), air permukaan 
hidrogel dilap dengan kertas saring dan ditimbang bobot basah (Wb). Hidrogel kemudian dikeringkan dalam oven pada suhu $60{ }^{\circ} \mathrm{C}$ selama 24 jam, lalu ditimbang (Wa). Daya serap air dihitung dengan rumus berikut:

$$
\text { Air terserap }=\frac{(W s-W d)}{W d} \times 100 \%
$$

Wd merupakan berat hidrogel dalam kondisi kering (g) dan Ws merupakan berat hidrogel dalam kondisi basah (g) pada selang waktu tertentu

\section{Pengujian Pelepasan Propanolol $\mathrm{HCl}$}

Hidrogel yang telah mengandung obat direndam dalam $50 \mathrm{~mL}$ media uji $\mathrm{pH} 6,8$ pada suhu $37^{\circ} \mathrm{C}$ dan dimasukkan ke dalam alat shaker incubator dengan kecepatan $100 \mathrm{rpm}$. Pengamatan konsentrasi propanolol $\mathrm{HCl}$ yang dilepaskan dari hidrogel dilakukan pada menit ke 10 , ke 15 , ke 30 , ke 45 , dan ke 60 , selanjutnya pada jam ke 2, ke 3, ke 4, ke 5, ke 6, dan ke 24 . Pada setiap waktu pengukuran, larutan sampel uji dipipet sebanyak $5 \mathrm{~mL}$ pada tempat yang sama dan volume diganti dengan larutan sesuai dengan jumlah yang sama. Larutan sampel tersebut ditetapkan konsentrasinya dengan spectrophotometer UV-Vis pada panjang gelombang serapan maksimum.

\section{HASIL DAN PEMBAHASAN}

\section{Fraksi Gel}

Fraksi gel merupakan salah satu parameter penting pada penelitian berkaitan dengan hidrogel yang mencerminkan seberapa banyak (\%) bahan awal dari polimer atau monomer yang diubah menjadi hidrogel pada proses polimerisasi. Selain itu, fraksi gel juga menunjukkan kerapatan ikatan silang dalam hidrogel (Shet et al. 2016; S. Lin dan Gu 2015). Hasil penetapan fraksi gel hidrogel PVAg-NaAlg dan hidrogel PVA sebagai kontrol hasil iradiasi pada dosis 10 kGy, 20 kGy, dan 30 kGy ditunjukkan pada Tabel 1, terlihat bahwa dengan meningkatnya dosis iradiasi dari $10 \mathrm{kGy}$ hingga 30kGy, fraksi gel PVA meningkat dari 93\% menjadi 98\% dan fraksi PVA-NaAlg meningkat dari $84 \%$ hingga $89 \%$. Secara umum terlihat bahwa dengan meningkatnya dosis iradiasi hingga 30 kGy, fraksi gel meningkat. Hal ini disebabkan oleh kerapatan silang hidrogel meningkat dengan meningkatnya dosis iradiasi dan fraksi gel yang relatif rendah pada hidrogel PVA-g-NAlg dibandingkan hidrogel PVA disebabkan terjadinya degradasi hidrogel PVA-g-NaAlg.

\section{Pengujian Absorbsi Air}

Pengujian absorbsi air oleh hidrogel berkaitan erat dengan kemampuan difusi air dalam matriks hidrogel melalui pori-pori yang membantu proses obat lepas dari hidrogel. Hubungan kemampuan hidrogel PVA-NaAlg dalam menyerap air terhadap lama waktu perendaman dengan variasi dosis iradiasi yang diukur pada $\mathrm{pH}$ 6,8 ditunjukkan pada Gambar 1.

Daya serap air oleh hidrogel pada $\mathrm{pH} 6,8$ dengan dosis $10 \mathrm{kGy}$ meningkat seiring dengan meningkatnya waktu perendaman dari jam pertama hingga jam ke-24 yaitu 2691,39\% sampai dengan $3671,76 \%$. Pada dosis $20 \mathrm{kGy}$, daya serap air meningkat dari $2947, \%$ sampai dengan $3285,86 \%$. Sedangkan pada dosis 30 kGy, daya serap air meningkat dari 1982,59\% sampai dengan 3077,14\%. Dengan kata lain, meningkatnya dosis iradiasi hingga $30 \mathrm{kGy}$, kemampuan hidrogel menyerap air menurun. Hal ini disebabkan meningkatnya dosis iradiasi mengakibatkan kerapatan silang hidrogel meningkat yang disertai kemampuan menyerap air menurun.

Secara umum, terlihat bahwa semua hidrogel hasil iradiasi berkemampuan menyerap air meningkat seiring dengan meningkatnya waktu perendaman hingga 24 jam. Gugus hydrophilic (PVA dan NaAlg) yang menyebabkan absorpsi air pada hidrogel gugus $\mathrm{OH}$ (hidoksi) atau asam yang terikat pada polimer.

Tabel 1. Fraksi gel hidrogel PVA, PVA-g-NaAlg, PVA-g-NaAlg mengandung propanolol $\mathrm{HCL}$ hasil iradiasi dosis $10 \mathrm{kGy}, 20 \mathrm{kGy}$, dan 30 kGy

\begin{tabular}{lccc}
\hline \multirow{2}{*}{ Hidrogel } & \multicolumn{3}{c}{ Dosis Iradiasi (kGy) } \\
\cline { 2 - 4 } & 10 & 20 & 30 \\
\hline PVA (5\%) & $93,09 \pm 1,13$ & $96,73 \pm 0,62$ & $98,07 \pm 0,82$ \\
PVA-NaAlg & $84,77 \pm 1,11$ & $87,77 \pm 0,76$ & $89,75 \pm 0,07$ \\
$(5 / 5 \%)$ & & & \\
\hline
\end{tabular}

${ }^{*}$ Catatan :pengujian fraksi gel dilakukan triplo

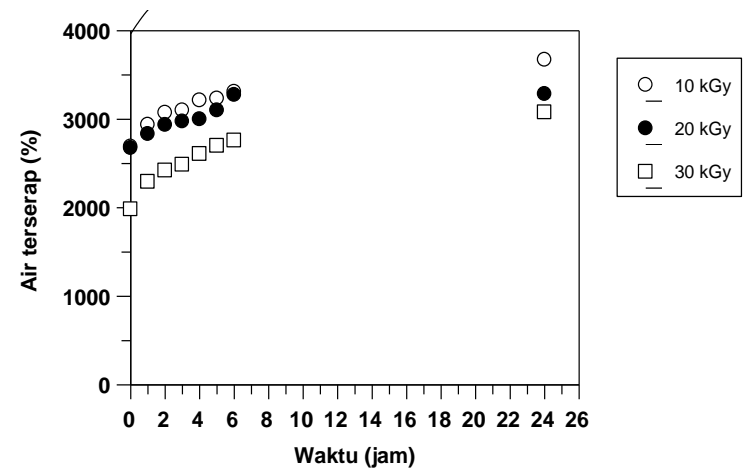

Gambar 1. Pengaruh waktu perendaman terhadap air terserap hidrogel PVA-g-NaAlg hasil iradiasi dosis $10 \mathrm{kGy}$ sampai dengan 30 kGy yang diukur pada $\mathrm{pH} \mathrm{6,8}$ 
Jika hidrogel direndam dalam air, air masuk ke dalam hidrogel melalui tekanan osmosis dan atom hidrogen bereaksi dan menghasilkan ion positif. Hal ini menyisakan ion negatif sepanjang rantai polimer. Ion-ion negatif tersebut saling tolak menolak dan menyebabkan rantai menjadi terbuka lebar dan menarik molekul air kemudian mengikatnya melalui ikatan hidrogen (Kalhapure dan Pradesh 2016).

\section{Profil Disolusi Propanolol $\mathrm{HCl}$ dari Matriks Hidrogel}

Mekanisme imobilisasi obat berdasarkan metode kombinasi beku-leleh dan iradiasi secara umum dapat diilustrasikan pada Gambar 2.

Pada keadaan awal (2a), mula-mula obat dicampurkan ke dalam PVA-NaAlg. PVA yang merupakan polimer linier tercampur secara sempurna dengan NaAlg melalui ikatan hidrogen, serta propanolol HCL merupakan senyawa yang larut dalam air tercampur secara sempurna dalam larutan tersebut. Keadaan (2b) dilakukan beku-leleh, pada kondisi tersebut PVA mengalami ikatan silang secara fisik baik dengan molekulnya sendiri dan juga dengan molekul NaAlg. Obat akan terperangkap dalam matriks hidrogel yang sudah beku tersebut. Selanjutnya dilakukan pelelehan, pada kondisi tersebut sebagian air mencair dan obat masuk ke dalam matriks hidrogel. Pada kondisi pembekuan selanjutnya, ikatan silang fisik PVANaAlg akan meningkat dan obat terperangkap ke dalam jaringan matriks hidrogel. Semakin sering dilakukan proses beku-leleh tersebut mengakibatkan semakin meningkat ikatan silang hidrogel. Lebih jauh lagi, pada proses iradiasi (2c) obat akan terlindung dengan air yang membeku pada saat iradiasi, sehingga obat tidak mengalami degradasi saat diiradiasi. Selain itu, kemungkinan terjadi ikatan silang antara PVA dan NaAlg meningkat dengan meningkatnya dosis iradiasi.

Pengaruh waktu perendaman hingga 24 jam terhadap kumulatif propanolol $\mathrm{HCl}$ yang lepas pada $\mathrm{pH}$ 6,8 dari matriks hidrogel PVANaAlg hasil iradiasi beragam dosis (10 kGy sampai dengan $30 \mathrm{kGy}$ ) dengan kandungan obat $8 \mathrm{mg}$ disajikan pada Gambar 3.

Dari Gambar 3 terlihat bahwa pada awal pengujian 15 menit pertama, kemampuan pelepasan obat dari ketiga hidrogel tersebut dengan beragam dosis iradiasi (10 kGy sampai dengan $30 \mathrm{kGy}$ ), kumulatif obat yang lepas dari matriks hidrogel relatif besar pada kisaran $32 \%$ sampai dengan $34 \%$. Terjadinya pelepasan obat yang relatif besar pada pengujian ini dikenal sebagai burst effect yaitu terlepasnya obat secara tidak terkontrol yang berasal dari permukaan hidrogel atau disebabkan ukuran partikel (Rizi et al. 2011). Pelepasan obat pada jam berikutnya (jam ke 2 hingga jam ke 24) mengikuti pola pelepasan obat secara eksponensial pada umumnya. Pada pengujian jam ke 4, jumlah obat yang lepas dari ketiga hidrogel tersebut adalah pada kisaran $48 \%$ sampai dengan $59 \%$ dan obat yang lepas pada pengujian jam ke 8 adalah pada kisaran $55 \%$ sampai dengan $68 \%$. Ditinjau dari pengaruh dosis iradiasi, pada Gambar 3 terlihat bahwa dengan meningkatnya dosis iradiasi hingga 30 kGy menyebabkan kemampuan lepas obat dari hidrogel menurun mencapai 55\%. Persentase pelepasan propanolol dari ketiga hidrogel ini sesuai persyaratan USP 31

Selain dari hal tersebut diatas, dengan menarik hubungan antara sumbu $Y$ (kumulatif persen obat) terhadap sumbu $X$ (waktu perendaman) pada rentang waktu jam ke 2 hingga jam ke 8, maka dapat diperoleh suatu segi tiga siku-siku. Berdasarkan hubungan tersebut $(\mathrm{y} / \mathrm{x})$ dapat diperkirakan laju lepas obat dari masing-masing hidrogel hasil iradiasi yang mengandung propanolol $\mathrm{HCl}(8 \mathrm{mg})$ disajikan pada Tabel 2.

Laju lepas propanolol $\mathrm{HCl}$ dari hidrogel dengan kandungan $12 \mathrm{mg}$ dan $16 \mathrm{mg}$ hasil iradiasi 10 kGy, 20 kGy, dan 30 kGy (Gambar 4a dan Gambar 4b.) secara berturut-turut disajikan pada Tabel 3 dan Tabel 4.

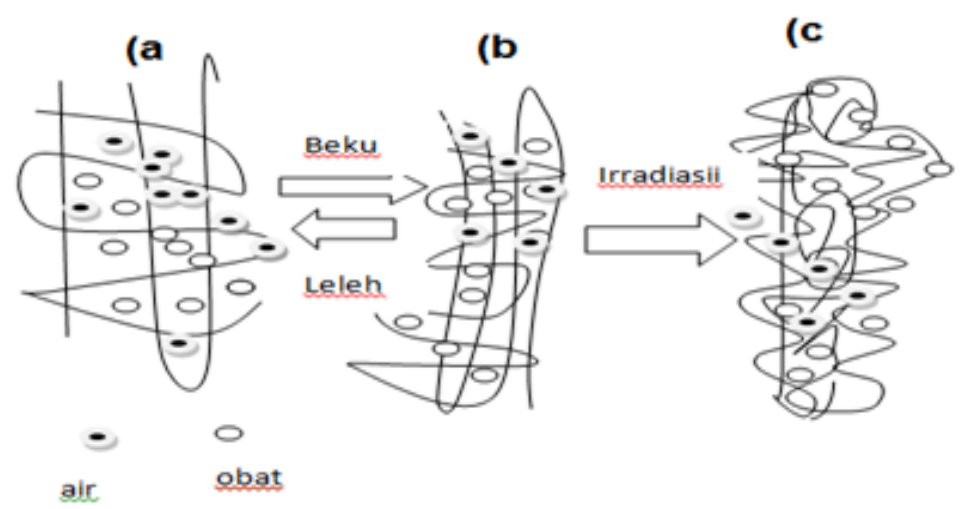

Gambar 2. Skema Imobilisasi obat dalam matrik hidrogel dengan kombinasi proses beku-leleh dan iradiasi 
Tabel 2. Laju pelepasan propanolol HCL dalam larutan $\mathrm{pH}$ 6,8 dari hidrogel hasil iradiasi berbeda dengan kandungan propanolol adalah $8 \mathrm{mg}$

\begin{tabular}{cc}
\hline $\begin{array}{c}\text { Hidrogel hasil iradiasi } \\
\text { dosis (kGy) }\end{array}$ & $\begin{array}{c}\text { Laju lepas obat } \\
(\mathrm{mg} / \mathrm{j}) \times 10^{-2}\end{array}$ \\
\hline 10 & 7 \\
20 & 5 \\
30 & 5 \\
\hline
\end{tabular}

Tabel 3. Laju pelepasan propanolol HCL dalam larutan $\mathrm{pH}$ 6,8 dari hidrogel hasil iradiasi berbeda dengan kandungan propanolol adalah $12 \mathrm{mg}$

\begin{tabular}{cc}
\hline $\begin{array}{c}\text { Hidrogel hasil iradiasi dosis } \\
\text { (kGy) }\end{array}$ & $\begin{array}{c}\text { Laju lepas obat } \\
(\mathrm{mg} / \mathrm{j}) \times 10^{-2}\end{array}$ \\
\hline 10 & 7 \\
20 & 6 \\
30 & 5 \\
\hline
\end{tabular}

Dari Tabel 3 dan Tabel 4 terlihat bahwa dengan meningkatnya dosis iradiasi, laju lepas propanolol $\mathrm{HCl}$ dari hidrogel menurun, sedangkan dengan meningkatnya kandungan obat, laju lepas obat meningkat. Hal ini mengindikasikan bahwa kerapatan silang meningkat dengan meningkatnya dosis iradiasi yang menyebabkan kemampuan laju lepas obat akan berkurang.

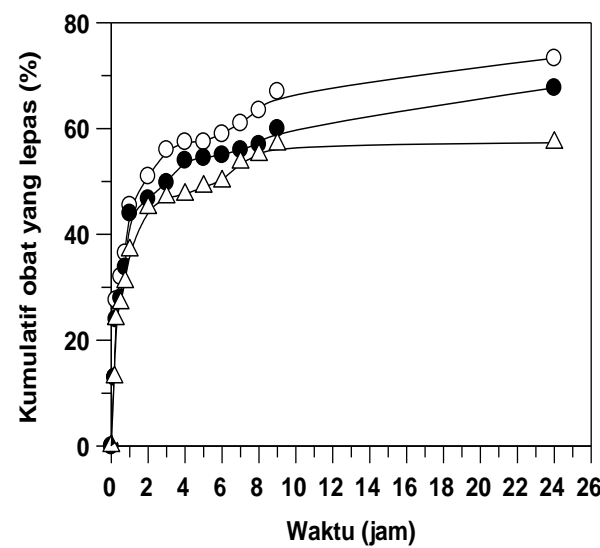

○ 10 kGy

- 20 kGy

$\triangle 30 \mathrm{kGy}$ larutan $\mathrm{PH}$ 6,8 dari hidrogel hasil iradiasi berbeda dengan kandungan propanolol adalah $16 \mathrm{mg}$

\begin{tabular}{cc}
\hline $\begin{array}{c}\text { Hidrogel hasil iradiasi } \\
\text { dosis (kGy) }\end{array}$ & $\begin{array}{c}\text { Laju lepas obat } \\
(\mathrm{mg} / \mathrm{j}) \times 10^{-2}\end{array}$ \\
\hline 10 & 6 \\
20 & 5 \\
30 & 5 \\
\hline
\end{tabular}

Waktu (jam)

Gambar 3. Profil disolusi propanolol $\mathrm{HCl}$ dalam larutan $\mathrm{pH}$ 6,8 dari hidrogel PVA-g-NaAlg hasil iradiasi dosis 10 kGy sampai dengan 30 kGy mengandung $8 \mathrm{mg}$ propanolol $\mathrm{HCl}$
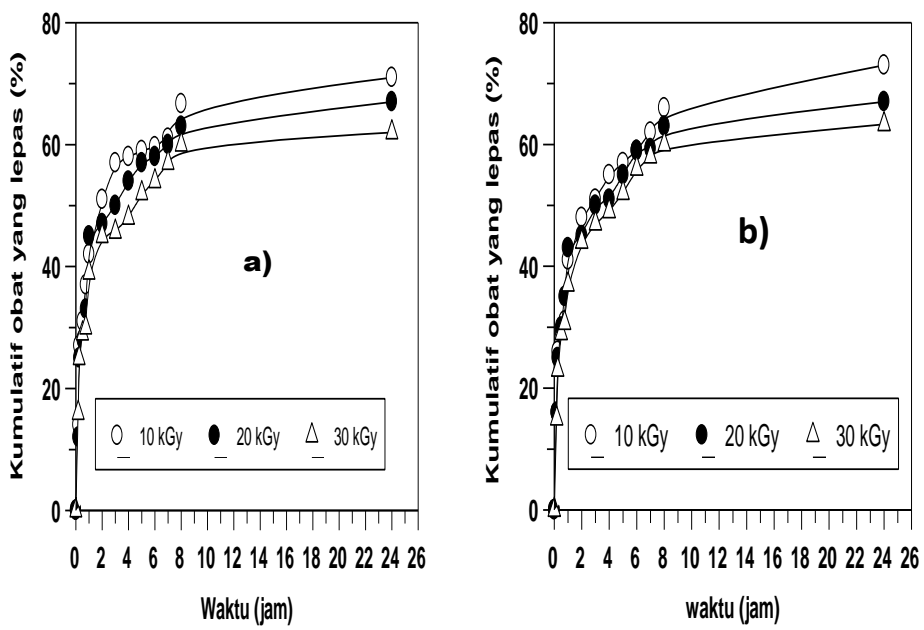

Gambar 4. Profil disolusi propanolol $\mathrm{HCl}$ dalam larutan $\mathrm{pH} \mathrm{6,8}$ dari hidrogel PVA-g-NaAlg hasil iradiasi dosis 10 kGy sampai dengan 30 kGy dengan variasi kandungannya a) $12 \mathrm{mg}$ dan b) $16 \mathrm{mg}$ 


\section{Spektrum FTIR}

Spektrum FT-IR PVA, NaAlg, dan hidrogel PVA-NaAlg hasil pengukuran disajikan pada Gambar 5. Dari Gambar 5, terlihat bahwa spektrum PVA (Gambar 5a) dicirikan dengan pita absorbsi yang melebar pada daerah bilangan gelombang $3700 \mathrm{~cm}^{-1}$ sampai dengan $3000 \mathrm{~cm}^{-1}$ menunjukkan vibrasi ulur $-\mathrm{OH}$ dan vibrasi ulur gugus - $\mathrm{CH}$ terdapat di daerah bilangan gelombang $2924 \mathrm{~cm}^{-1}$. Spektrum natrium alginat menunjukkan pita-pita absorbsi yang penting seperti gugus hidroksil, eter, dan karboksilat.

Vibrasi tekuk ikatan - $\mathrm{OH}$ dari alginat tampak pada daerah bilangan gelombang $3000 \mathrm{~cm}^{-1}$ sampai dengan $3600 \mathrm{~cm}^{-1}$. Vibrasi tekuk gugus $\mathrm{C}-\mathrm{H}$ tampak pada daerah bilangan gelombang $2920 \mathrm{~cm}^{-1}$ sampai dengan $2850 \mathrm{~cm}$ , sedangkan gugus ion karboksilat simetris dan asimetris masing-masing tampak pada daerah bilangan gelombang $1611 \mathrm{~cm}^{-1}$ dan $1531 \mathrm{~cm}^{-1}$. Pita-pita spektrum $1611 \mathrm{~cm}^{-1}$ dan $1531 \mathrm{~cm}^{-1}$ tersebut sangat penting dan umumnya digunakan untuk karakterisasi struktur alginat seperti gugus vibrasi tekuk lingkar piranosil pada daerah bilangan gelombang $1107 \mathrm{~cm}^{-1}$ dan vibrasi tekuk $\mathrm{C}-\mathrm{O}$ yang berasal dari kontribusi deformasi gugus $\mathrm{C}-\mathrm{C}-\mathrm{H}$ dan $\mathrm{C}-\mathrm{O}-\mathrm{H}$ pada daerah bilangan gelombang $935 \mathrm{~cm}^{-1}$, sedangkan spektrum hidrogel PVA-NaAlg yang merupakan gabungan puncak-puncak gugus yang mewakili keduanya tampak dalam spektrumnya.

Ikatan hidrogen antara gugus $-\mathrm{OH}(\mathrm{v}=$ $3445 \mathrm{~cm}^{-1}$ ) yang terjadi antara molekul PVA disebabkan kekuatan hydrophilic yang besar (Kamoun et al. 2015) serta absorbsi yang tajam pada rentang bilangan gelombang $1150 \mathrm{~cm}^{-1}$ sampai dengan $1050 \mathrm{~cm}^{-1}$. Lebih jauh lagi, diperoleh pita tekuk pada rentangn bilangan gelombang $1549 \mathrm{~cm}^{-1}$ sampai dengan $1453 \mathrm{~cm}$ dari gugus $-\mathrm{CH}_{2}$ yang mewakili struktur kimia PVA dan paduan PVA-NaAlg polimer.

Pada Gambar 6 disajikan spektrum FTIR PVA-NaAlg hasil iradiasi hingga $30 \mathrm{kGy}$, terlihat bahwa dengan meningkatnya dosis iradiasi terjadi penciutan gugus $\mathrm{OH}$ (bilangan gelombang $3700 \mathrm{~cm}^{-1}$ sampai $3000 \mathrm{~cm}^{-1}$ dalam spektrum hidrogel PVA-NaAlg. Hal ini mungkin disebabkan dengan meningkatnya dosis iradiasi kerapatan silang hidrogel meningkat.

\section{SEM Hidrogel}

Photomicrograph Scanning Electron Microscope (SEM) memberikan informasi mengenai morfologi geometri pori-pori dan ukuran hidrogel pada lokasi yang spesifik. Foto SEM pada Gambar 7 memberikan informasi yang relevan berkatian dengan homogenitas dan heterogenitas jaringan hidrogel. Morfologi permukaan dan bagian dalam (interior) hidrogel PVA-g-NaAlg hasil iradiasi dengan perbesaran 500 kali disajikan pada Gambar 7.

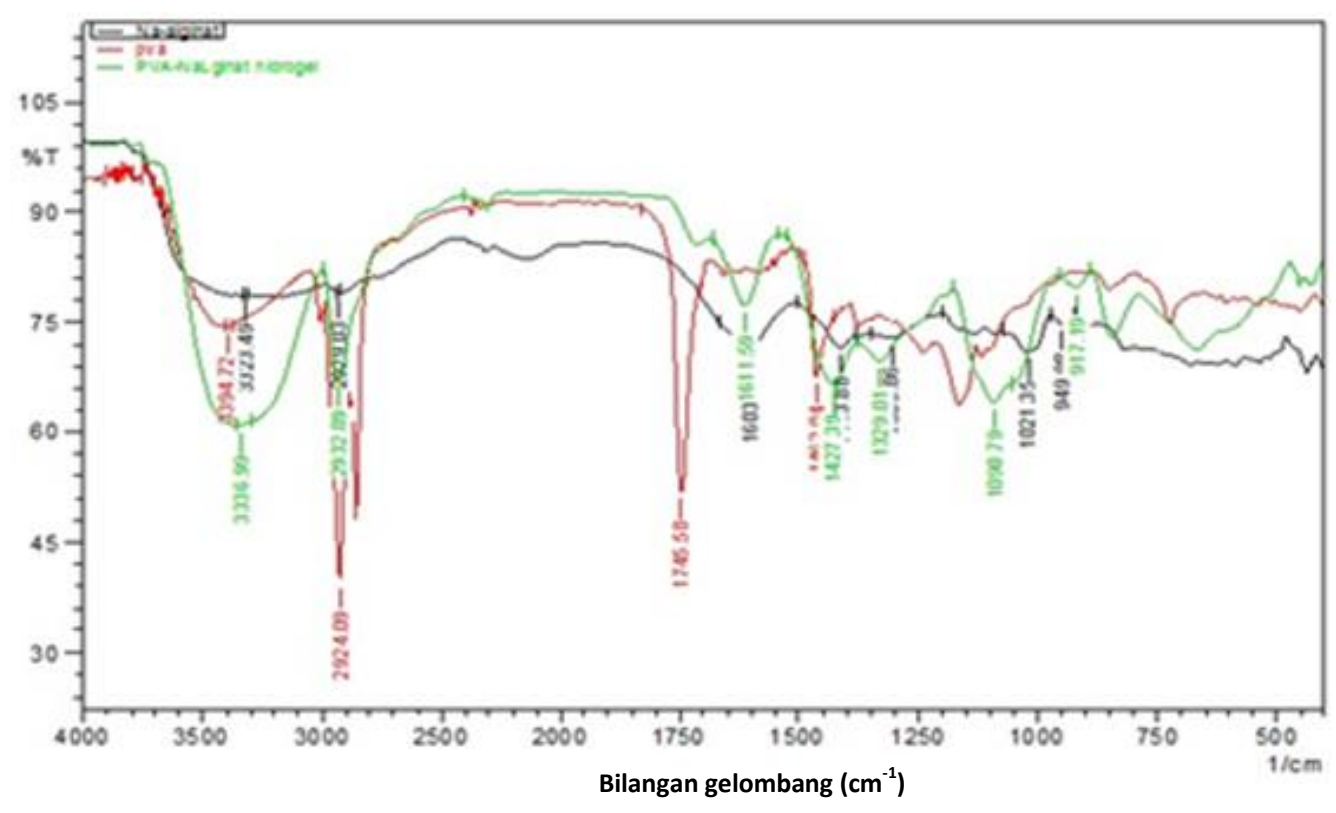

Gambar 5. Spektrum FT-IR a) PVA, b) Naalg, dan c) PVA-NaAlg hasil iradiasi 


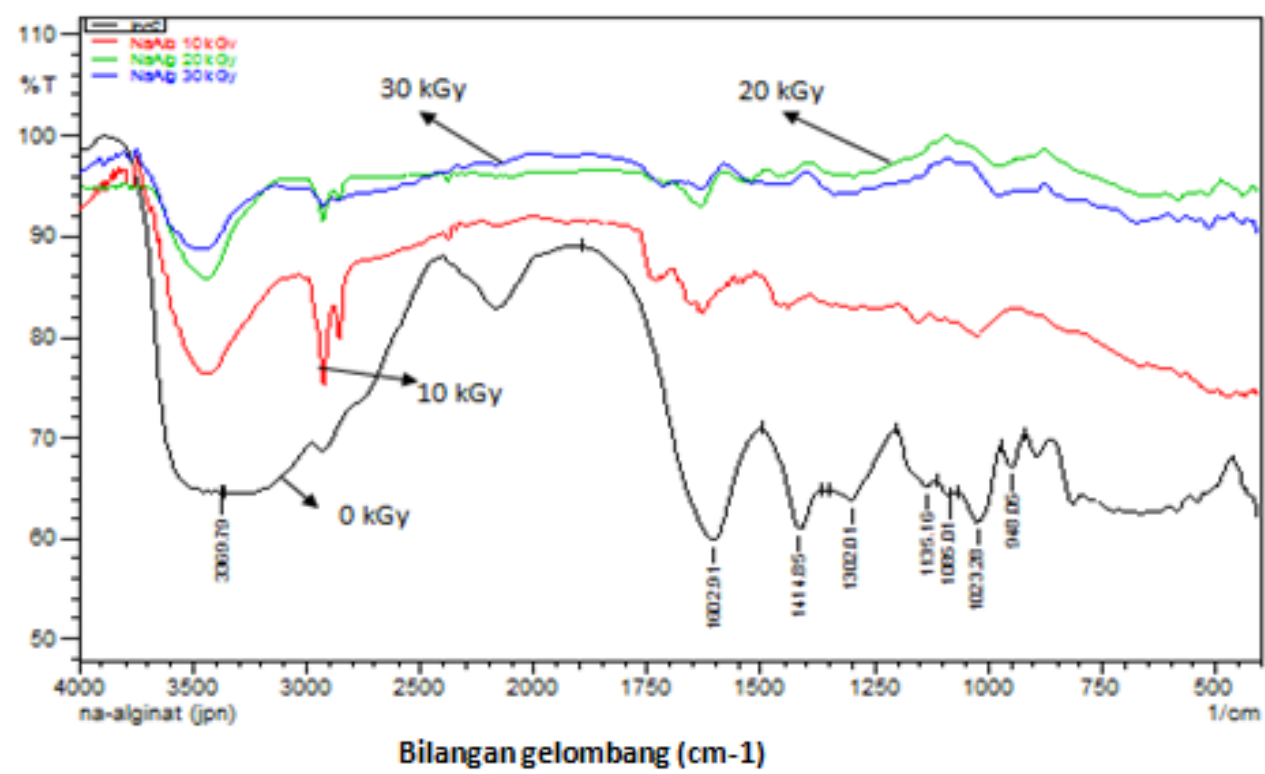

Gambar 6. Spektrum FT-IR PVA-NaAlg hasil iradiasi rentan dosis 0 kGy sampai dengan 30 kGy

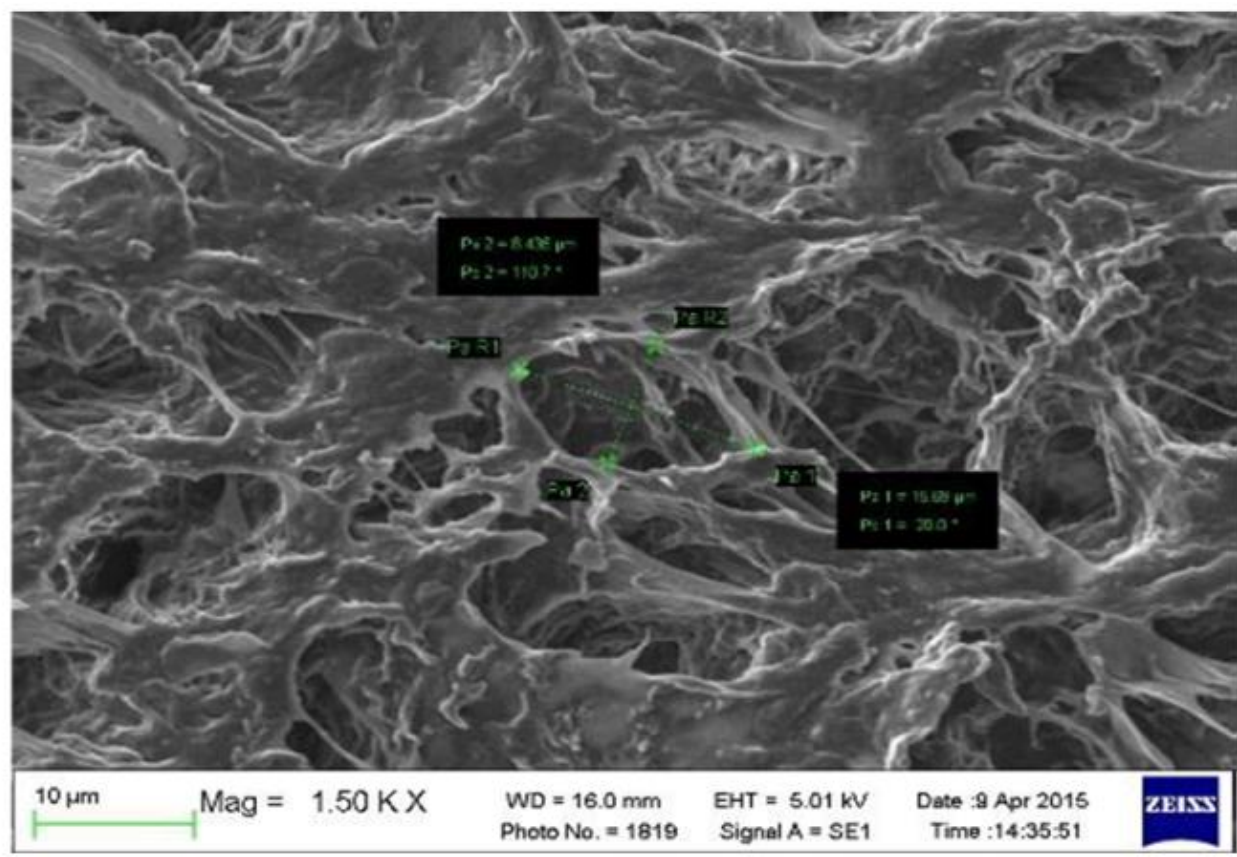

Gambar 7. Photomicrograph SEM hidrogel PVA-g-NaAlg hasil iradiasi 10 kGy dengan perbesaran 500 kali

Dari Gambar 7 terlihat bahwa permukaan hidrogel berserat yang terdiri dari pori-pori yang tidak teratur dengan kisaran ukuran pori $15 \mu \mathrm{m}$ sampai dengan $35 \mu \mathrm{m}$ dan di beberapa lokasi dilingkupi oleh kulit tebal polimer. Kulit tebal polimer tersebut kemungkinan disebabkan oleh runtuhnya permukaan pori pada proses freeze drying khususnya oleh pori yang besar dan kulit dinding hidrogel. Adanya pori-pori dari hidrogel ini merupakan salah satu faktor yang menyebabkan terjadinya pelepasan obat dari hidrogel melalui proses difusi air dalam pori.

\section{KESIMPULAN}

Propanolol $\mathrm{HCl}$ dapat diperangkap atau dijebak dalam matriks hidrogel PVA-g-NaAlg menggunakan kombinasi beku-leleh dan proses iradiasi gamma. Pelepasan $\mathrm{HCl}$ dipengaruhi oleh dosis radiasi yang digunakan untuk imobilisasi. Meningkatnya dosis iradiasi dari 10 kGy hingga 30 kGy mengakibatkan jumlah kumulatif obat yang lepas menurun. Hal ini disebabkan terjadinya peningkatan kerapatan silang dalam hidrogel, sehingga kemampuan obat yang lepas dari hidrogel menurun. 
Selain itu, kandungan obat yang dikekang dalam hidrogel mempengaruhi laju lepasnya dari matriks hidrogel. Pada umumnya, meningkatnya kandungan obat yang diiimobilisasi dalam matriks hidrogel mengakibatkan densitas obat dalam matriks hidrogel meningkat, hal ini menyebabkan pelepasan obat akan menjadi lebih besar ketika diuji dalam medium uji. Pola pelepasan obat dari matriks hidrogel mirip seperti pola penyerapan air pada hidrogel.

\section{UCAPAN TERIMA KASIH}

Ucapan terima kasih ditujukan kepada rekan-rekan di Iradiator IRPASENA yang telah membantu iradiasi sampel khususnya Bpk. Bonang.

\section{DAFTAR PUSTAKA}

Catelas, I., J. F. Dwyer, and S. A. M. Helgerson. 2008. "Controlled Release of Bioactive Transforming Growth Factor Beta-1 from Fibrin Gels in Vitro." Tissue Engineering 14 (2). doi:10.1089/ten.tec.2007.0262.

Chowdhury, M. A. 2014. "International Journal of Biological Macromolecules The Controlled Release of Bioactive Compounds from Lignin and Lignin-Based Biopolymer Matrices." International Journal of Biological Macromolecules 65: 136-147. doi:10.1016/j.ijbiomac.2014.01.012.

Defail, A. J., H. D. Edington, S. Matthews, W. C. Lee, and K. G. Marra. 2006. "Controlled Release of Bioactive Doxorubicin from Microspheres Embedded within Gelatin Scaffolds." Journal of Biomedical Materials Research 79A(4):2-4. doi:10.1002/jbm.a.

Dutta, J. 2012. "Synthesis and Characterization of $y$-Irradiated PVA/PEG/ $\mathrm{CaCl}_{2}$ Hydrogel for Wound Dressing." American Journal of Chemistry 2 (2): 6-11. doi:10.5923/j.chemistry.20120202.02.

El-mohdy, H. L. A. 2013. "Radiation Synthesis of Nanosilver/Poly Vinyl Alcohol/Cellulose Acetate/Gelatin Hydrogels for Wound Dressing." Journal of Polymer Research 20(6). doi:10.1007/s10965-013-0177-6.

Elliott, I., and M. S. Shoichet. 2015. "Acta Biomaterialia Controlled Release of Bioactive PDGF-AA from A Hydrogel/Nanoparticle Composite." Acta Biomaterialia 25:35-42. doi:10.1016/j.actbio.2015.08.002.

Erizal, E., and Z. Abidin. 2011. "Sintesis Hidrogel Campuran Poli (Vinil Alkohol) (PVA)Natrium Alginat Dengan Kombinasi BekuLeleh Dan Radiasi Gamma Untuk Bahan Pembalut Luka Synthesis Of Hydrogel Poly (Vinyl Alcohol) (PVA)-Sodium
Alginate Blend by Freeze-Thawing Followed by Ga." Jurnal IImiah Aplikasi Isotop Dan Radiasi 7: 21-28.

Guo, L., H. Zhang, D. Fortin, H. Xia, and Y. Zhao. 2015. "Poly (Vinyl Alcohol)-Poly (Ethylene Glycol) Double-Network Hydrogel: A General Approach to Shape Memory and Self-Healing Functionalities Poly (Vinyl Alcohol)-Poly (Ethylene Glycol) Double-Network Hydrogel: A General Approach to Shape Memory an." Langmuir 31(42): 11709-11716. doi:10.1021/acs.langmuir.5b03474.

Hoare, T. R., and D. S. Kohane. 2008. "Hydrogels in Drug Delivery: Progress and Challenges *." Polymer 49 (8): 19932007. doi:10.1016/j.polymer.2008.01.027.

Hudson, S. P., R. Langer, G. R. Fink, and D. S. Kohane. 2010. "Biomaterials Injectable in Situ Cross-Linking Hydrogels for Local Antifungal Therapy." Biomaterials 31 (6): 1444-1452. doi:10.1016/j.biomaterials.2009.11.016.

Kalhapure, A., and U. Pradesh. 2016. "Hydrogels: A Boon for Increasing Agricultural Productivity in Water-Stressed Environment." Current Science 111 (11): 1773-1779. doi:10.18520/cs/v111/i11/1773-1779.

Kamoun, E. A., X. Chen, M. S. Mohy, and E. S. Kenawy. 2015. "Crosslinked Poly (Vinyl Alcohol) Hydrogels for Wound Dressing Applications: A Review of Remarkably Blended Polymers." Arabian Journal of Chemistry 8 (1): 1-14. doi:10.1016/j.arabjc.2014.07.005.

Lee, M., H. Bae, S. Lee, N. Chung, H. Lee, S. Choi, S. Hwang, and J. Lee. 2011. "Freezing/Thawing Processing of PVA in the Preparation of Structured Microspheres for Protein Drug Delivery." Macromolecular Research 19 (2): 130136. doi:10.1007/s13233-011-0203-7.

Lin, C., and A. T. Metters. 2006. "Hydrogels in Controlled Release Formulations: Network Design and Mathematical Modeling 2 . . Adv Drug Deliv Rev. 58 (1213):1379-1408. doi:10.1016/j.addr.2006.09.004.

Lin, S., and L. Gu. 2015. "Influence of Crosslink Density and Stiffness on Mechanical Properties of Type I Collagen Gel." Materials (Basel). 8 (2): 551-560. doi:10.3390/ma8020551.

Masuelli, M. A., and C. O. Illanes. 2014. "Review of the Characterization of Sodium Alginate by Intrinsic Viscosity Measurements.Comparative Analysis between Conventional and Single Point Methods." International Journal of BioMaterials Science and Engineering 1 (1): 1-11. 
Rizi, K., R .J. Green, O. Khutoryanskaya, M. Donaldson, and A. C. Williams. 2011. "Mechanisms of Burst Release from $\mathrm{pH}$ Responsive Polymeric Microparticles." J Pharm Pharmacol.63(9):1145-1155.

Sylman, J. L., and K. B. Neeves. 2013. "An Inquiry-Based Investigation of ControlledRelease Drug Delivery from Hydrogels: An Experiment for High School Chemistry and Biology." J. Chem. Educ 90 (7): 918-
921.

Wong, R. S. H., M. Ashton, and K. Dodou. 2016. "Analysis of Residual Crosslinking Agent Content in UV Cross-Linked Poly (Ethylene Oxide) Hydrogels for Dermatological Application by Gas Chromatography." Journal of Pharmaceutical Analysis 6(2016) : 307312. 